\title{
Front Matter: Volume 8810
}

, "Front Matter: Volume 8810," Proc. SPIE 8810, Optical Trapping and Optical Micromanipulation X, 881001 (1 October 2013); doi: 10.1117/12.2034138

SPIE Event: SPIE NanoScience + Engineering, 2013, San Diego, California, United SPIE. States 


\title{
PROCEEDINGS OF SPIE
}

\section{Optical Trapping and Optical Micromanipulation $X$}

\author{
Kishan Dholakia \\ Gabriel C. Spalding \\ Editors
}

25-29 August 2013

San Diego, California, United States

Sponsored by

SPIE

Cosponsored by

Elliot Scientific Ltd. (United Kingdom)

nPoint, Inc. (United States)

Thorlabs Inc.

Published by

SPIE 
The papers included in this volume were part of the technical conference cited on the cover and title page. Papers were selected and subject to review by the editors and conference program committee. Some conference presentations may not be available for publication. The papers published in these proceedings reflect the work and thoughts of the authors and are published herein as submitted. The publisher is not responsible for the validity of the information or for any outcomes resulting from reliance thereon.

Please use the following format to cite material from this book:

Author(s), "Title of Paper," in Optical Trapping and Optical Micromanipulation X, edited by Kishan Dholakia, Gabriel C. Spalding, Proceedings of SPIE Vol. 8810 (SPIE, Bellingham, WA, 2013) Article CID Number.

ISSN: 0277-786X

ISBN: 9780819496607

Published by

SPIE

P.O. Box 10, Bellingham, Washington 98227-0010 USA

Telephone +1 3606763290 (Pacific Time) · Fax +1 3606471445

SPIE.org

Copyright @ 2013, Society of Photo-Optical Instrumentation Engineers.

Copying of material in this book for internal or personal use, or for the internal or personal use of specific clients, beyond the fair use provisions granted by the U.S. Copyright Law is authorized by SPIE subject to payment of copying fees. The Transactional Reporting Service base fee for this volume is $\$ 18.00$ per article (or portion thereof), which should be paid directly to the Copyright Clearance Center (CCC), 222 Rosewood Drive, Danvers, MA 01923. Payment may also be made electronically through CCC Online at copyright.com. Other copying for republication, resale, advertising or promotion, or any form of systematic or multiple reproduction of any material in this book is prohibited except with permission in writing from the publisher. The CCC fee code is 0277-786X/13/\$18.00.

Printed in the United States of America.

Publication of record for individual papers is online in the SPIE Digital Library.

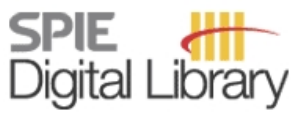

SPIEDigitalLibrary.org

Paper Numbering: Proceedings of SPIE follow an e-First publication model, with papers published first online and then in print and on CD-ROM. Papers are published as they are submitted and meet publication criteria. A unique, consistent, permanent citation identifier (CID) number is assigned to each article at the time of the first publication. Utilization of CIDs allows articles to be fully citable as soon as they are published online, and connects the same identifier to all online, print, and electronic versions of the publication. SPIE uses a six-digit CID article numbering system in which:

- The first four digits correspond to the SPIE volume number.

- The last two digits indicate publication order within the volume using a Base 36 numbering system employing both numerals and letters. These two-number sets start with 00, 01, 02, 03, 04, $05,06,07,08,09,0 A, 0 B \ldots$. OZ, followed by 10-1Z, 20-2Z, etc.

The CID Number appears on each page of the manuscript. The complete citation is used on the first page, and an abbreviated version on subsequent pages. Numbers in the index correspond to the last two digits of the six-digit CID Number. 


\section{Contents}

Conference Committee

TRACTOR BEAMS AND THE POSITIVES AND NEGATIVES OF RADIATION PRESSURE

881003 Experimental demonstration of optical transport, sorting and self-arrangement using a "tractor beam" [8810-2]

O. Brzobohatý, V. Karásek, M. Šiler, L. Chvátal, Institute of Scientific Instruments of the ASCR, v.v.i. (Czech Republic); T. Čižmár, Univ. of St. Andrews (United Kingdom); P. Zemánek, Institute of Scientific Instruments of the ASCR, v.v.i. (Czech Republic)

881004 Mapping out tractor beams: topological angular momentum and reduced axial flux; gradient versus non-conservative forces [8810-3]

G. C. Spalding, Illinois Wesleyan Univ. (United States); P. M. Dahl, Illinois Wesleyan Univ. (United States) and Univ. of Dundee (United Kingdom); C. E. M. Démoré, Z. Yang, Univ. of Dundee (United Kingdom); P. Glynne-Jones, Univ. of Southampton (United Kingdom);

A. Melzer, S. Cochran, M. P. MacDonald, Univ. of Dundee (United Kingdom)

881006 Properties of oscillating refractive optical wings with one reflective surface [8810-5] A. B. Artusio-Glimpse, G. A. Swartzlander Jr., Rochester Institute of Technology (United States)

$881007 \quad$ Non-conservative scattering forces on small particles [8810-6]

M. I. Marqués, J. J. Sáenz, Univ. Autónoma de Madrid (Spain)

\section{'GONZO' TRAPPING}

881009 Optical tweezing at extremes (Invited Paper) [8810-8]

G. M. Gibson, Univ. of Glasgow (United Kingdom); R. W. Bowman, Univ. of Glasgow (United Kingdom) and Univ. of Cambridge (United Kingdom); F. Saglimbeni, R. Di Leonardo, Univ. degli Studi di Roma La Sapienza (Italy); M. J. Padgett, Univ. of Glasgow (United Kingdom)

\section{TOWARD (OR IN) THE QUANTUM LIMIT OF OPTO-MECHANICS}

8810 OB Testing quantum physics in space using optically trapped nanospheres (Invited Paper) [8810-10]

R. Kaltenbaek, Univ. of Vienna (Austria)

8810 OE Quantitatively measuring the orbital angular momentum density of light [8810-13] A. Dudley, CSIR National Laser Ctr. (South Africa); C. Schulze, Friedrich Schiller Univ. (Germany); I. Litvin, CSIR National Laser Ctr. (South Africa); M. Duparré, Friedrich Schiller Univ. (Germany); A. Forbes, CSIR National Laser Ctr. (South Africa) and Univ. of KwaZuluNatal (South Africa) and Stellenbosch Univ. (South Africa) 
$88100 \mathrm{~J}$ The kinetic subsystem of light and its role in optical manipulation [8810-19]

B. A. Kemp, Arkansas State Univ. (United States)

8810 OK The force law of classical electrodynamics: Lorentz versus Einstein and Laub [8810-20]

M. Mansuripur, College of Optical Sciences, Univ. of Arizona (United States)

\section{OPTICAL MANIPULATION OF MATTER THROUGH GASEOUS MEDIA}

8810 ON Quasi-Bessel hollow beam as optical guide for micro-particles [8810-23]

L. Li, Australian National Univ. (Australia) and Sun Yat-sen Univ. (China); N. Eckerskorn, Australian National Univ. (Australia); R. A. Kirian, Ctr. for Free-Electron Laser Science, DESY (Germany); J. Küpper, Ctr. for Free-Electron Laser Science, DESY (Germany) and Univ. of Hamburg (Germany) and The Hamburg Ctr. for Ultrafast Imaging (Germany);

D. P. DePonte, Ctr. for Free-Electron Laser Science, DESY (Germany); W. Krolikowski, W. M. Lee, Australian National Univ. (Australia); H. N. Chapman, Ctr. for Free-Electron Laser Science, DESY (Germany) and Univ. Of Hamburg (Germany) and The Hamburg Ctr. for Ultrafast Imaging (Germany); A. V. Rode, Australian National Univ. (Australia)

$881000 \quad$ Manipulation of optically levitated particles [8810-24]

O. Isaksson, Chalmers Univ. of Technology (Sweden) and Univ. of Gothenburg (Sweden); M. Karlsteen, Chalmers Univ. of Technology (Sweden); M. Rostedt, D. Hanstorp, Univ. of Gothenburg (Sweden)

8810 OP Dye lasing in optically manipulated liquid aerosols [8810-25]

Y. Karadag, M. Aas, A. Jonáš, Koç Univ. (Turkey); S. Anand, D. McGloin, Univ. of Dundee (United Kingdom); A. Kiraz, Koç Univ. (Turkey)

\section{PHOTONIC DEVICES FOR OPTICALLY INDUCED FORCES}

8810 OT Optical waveguide loop for planar trapping of blood cells and microspheres [8810-29]

B. S. Ahluwalia, O. G. Hellesø, Univ. of Tromsø (Norway)

\section{PLASMONIC AND NANOPARTICLE TRAPPING}

8810 OU Plasmonic nanotweezers based on Au bowtie nanoantenna arrays for manipulation of nano-to-macroscopic objects (Invited Paper) [8810-30]

K. C. Toussaint, B. J. Roxworthy, Univ. of Illinois at Urbana-Champaign (United States)

$8810 \mathrm{OW}$ Measurement of the signal from a single DNA molecule trapped by a nanoplasmonic structure [8810-32]

J.-D. Kim, W. Muhammad, Y.-G. Lee, Gwangju Institute of Science and Technology (Korea, Republic of) 
881012 Particle dynamics in a virtual harmonic potential [8810-38]

M. Gavrilov, Y. Jun, J. Bechhoefer, Simon Fraser Univ. (Canada)

881013 Frustration effects and grain boundaries in colloidal particle orderings on optical substrates [8810-39]

D. McDermott, Los Alamos National Lab. (United States) and Univ. of Notre Dame (United States); A. Libál, Babes-Bolyai Univ. (Romania); G. W. Chern, C. Reichhardt,

C. J. Olson Reichhardt, Los Alamos National Lab. (United States)

881015 Exploiting the color of Brownian motion for high-frequency microrheology of Newtonian fluids [8810-41]

P. Domínguez-García, Univ. Nacional de Educación a Distancia (Spain) and Ecole Polytechnique Fédérale de Lausanne (Switzerland); F. M. Mor, L. Forró, S. Jeney, Ecole Polytechnique Fédérale de Lausanne (Switzerland)

\section{STUDIES OF ACTIVE SWIMMERS/HYDRODYNAMICS}

881016 Self-driven particles on asymmetric trap arrays [8810-42]

L. M. Lopatina, C. Reichhardt, C. J. Olson Reichhardt, Los Alamos National Lab. (United States)

\section{SINGLE-MOLECULE MANIPULATION AND STUDY}

$88101 \mathrm{E} \quad$ Ultra-fast force-clamp laser trapping of single molecular motors and DNA binding proteins [8810-49]

M. Capitanio, European Lab. for Non-linear Spectroscopy (Italy) and Univ. degli Studi di Firenze (Italy); C. Monico, European Lab. for Non-linear Spectroscopy (Italy); F. Vanzi, European Lab. for Non-linear Spectroscopy (Italy) and Univ. degli Studi di Firenze (Italy); F. S. Pavone, European Lab. for Non-linear Spectroscopy (Italy) and Univ. degli Studi di Firenze (Italy) and National Institute of Optics-CNR and International Ctr. of Computational Neurophotonics (Italy)

$88101 \mathrm{~F} \quad$ Dynamic single-molecule force spectroscopy using optical tweezers and nanopores [8810-50]

N. Laohakunakorn, Univ. of Cambridge (United Kingdom); O. Otto, Technische Univ. Dresden (Germany); S. Sturm, K. Kroy, Univ. Leipzig (Germany); U. F. Keyser, Univ. of Cambridge (United Kingdom)

$88101 \mathrm{G}$ Why soft UV-A damages DNA: An optical micromanipulation study [8810-51] A. Rapp, Technical Univ. Darmstadt (Germany) and Leibniz Institute for Age Research (Germany); K. Greulich, Leibniz Institute for Age Research (Germany)

$88101 \mathrm{H} \quad$ Magnetic trapping of single molecules: principles, developments, and applications (Invited Paper) [8810-52]

W. Grange, T. R. Strick, Institut Jacques Monod, CNRS, Univ. Paris Diderot (France) 
$88101 \mathrm{~L} \quad$ Designing an experiment to measure cellular interaction forces [8810-56] N. McAlinden, D. G. Glass, O. R. Millington, Univ. of Strathclyde (United Kingdom); A. J. Wright, The Univ. of Nottingham (United Kingdom)

$88101 \mathrm{~N}$ New biodiagnostics based on optical tweezers: typing red blood cells, and identification of drug resistant bacteria (Invited Paper) [8810-58]

J.-W. Chen, Feng-Yuan Hospital (Taiwan); C.-F. Lin, S.-G. Wang, Y.-C. Lee, C.-H. Chiang, M.-H. Huang, Central Taiwan Univ. of Science and Technology (Taiwan); Y.-H. Lee, Feng Chia Univ. (Taiwan); G. Vitrant, IMEP-LAHC, Grenoble-INP, CNRS (France); M.-J. Pan, H.-M. Lee, Central Taiwan Univ. of Science and Technology (Taiwan); Y.-J. Liu, Feng Chia Univ. (Taiwan); P. L. Baldeck, Univ. Grenoble, CNRS (France) and Central Taiwan Univ. of Science and Technology (Taiwan); C.-L. Lin, Central Taiwan Univ. of Science and Technology (Taiwan)

\section{OPTICALLY DRIVEN MICRORHEOLOGY AND MECHANICAL PROPERTIES}

881010 Evaluating cell matrix mechanics using an integrated nonlinear optical tweezer-confocal imaging system [8810-59] B. Peng, C. A. C. Alonzo, L. Xia, Tufts Univ. (United States); L. Speroni, Tufts Univ. School of Medicine (United States); I. Georgakoudi, Tufts Univ. (United States); A. M. Soto, C. Sonnenschein, Tufts Univ. School of Medicine (United States); M. Cronin-Golomb, Tufts Univ. (United States)

$88101 \mathrm{P} \quad$ Probing multiscale mechanics of collagen with optical tweezers [8810-60] M. Shayegan, N. Rezaei, N. H. Lam, T. Altindal, A. Wieczorek, N. R. Forde, Simon Fraser Univ. (Canada)

8810 IR Optical manipulation of vesicles for optofluidic applications [8810-62]

A. E. Vasdekis, Pacific Northwest National Labs. (United States); E. A. Scott, C. P. O'Neil, D. Psaltis, J. A. Hubbell, Ecole Polytechnique Fédérale de Lausanne (Switzerland)

\section{OPTOFLUIDICS AND OPTICALLY SHAPED STRUCTURES}

$8810 \mathrm{lV}$ Laser trapping dynamics of $200 \mathrm{~nm}$-polystyrene particles at a solution surface [8810-66] K. Yuyama, National Chiao Tung Univ. (Taiwan); T. Sugiyama, Instrument Technology Research Ctr. (Taiwan); H. Masuhara, National Chiao Tung Univ. (Taiwan)

8810 IW An optical platform for the production, trapping, manipulation and visualization of ultra-low interfacial tension emulsion droplets [8810-67]

A. L. Hargreaves, A. K. Kirby, C. D. Bain, G. D. Love, Univ. of Durham (United Kingdom); G. Bolognesi, O. Ces, M. Neil, Imperial College London (United Kingdom); A. D. Ward, Rutherford Appleton Lab. (United Kingdom)

$88101 Y$ Tunable optofluidic microlasers based on optically stretched emulsion droplets [8810-69] M. Aas, A. Jonáš, A. Kiraz, Koç Univ. (Turkey); O. Brzobohatvý, J. Ježek, Z. Pilát, P. Zemánek, Institute of Scientific Instruments of the ASCR, v.v.i. (Czech Republic) 
881022 Spatial light modulation for improved microscope stereo vision and 3D tracking [8810-73] M. P. Lee, G. Gibson, M. Tassieri, Univ. of Glasgow (United Kingdom); D. Phillips, Univ. of Bristol (United Kingdom); S. Bernet, M. Ritsh-Marte, Innsbruck Medical Univ. (Austria); M. J. Padgett, Univ. of Glasgow (United Kingdom)

\section{OPTICALLY BOUND MATTER}

881025 Near-field manipulation of interparticle forces through resonant absorption, optical binding, and dispersion forces [8810-76]

D. S. Bradshaw, D. L. Andrews, Univ. of East Anglia Norwich (United Kingdom)

881026 Optical binding of nanowires in counterpropagating beams [8810-77]

S. H. Simpson, Univ. of Bristol (United Kingdom); P. H. Jones, Univ. College London (United Kingdom); O. M. Maragò, CNR-IPCF (Italy); S. Hanna, M. J. Miles, Univ. of Bristol (United Kingdom)

$881027 \quad$ Optical sorting due to optical binding [8810-78]

V. Karásek, P. Zemánek, Institute of Scientific Instruments of the ASCR, v.v.i.

(Czech Republic)

\section{OPTICALLY MANIPULATED ROBOTICS AND NOVEL SAMPLES}

881028 A modular assembling platform for manufacturing of microsystems by optical tweezers [8810-79]

S. I. Ksouri, A. Aumann, R. Ghadiri, M. Prüfer, S. Baer, A. Ostendorf, Ruhr-Univ. Bochum (Germany)

881029 Fashioning microscopic tools [8810-80]

D. B. Phillips, Univ. of Bristol (United Kingdom) and Univ. of Glasgow (United Kingdom); G. Whyte, Erlangen-Nurnberg Univ. (Germany); D. M. Carberry, S. Hanna, M. J. Miles, Univ. of Bristol (United Kingdom); M. J. Padgett, Univ. of Glasgow (United Kingdom);

S. H. Simpson, Univ. of Bristol (United Kingdom)

8810 2A Heat in optical tweezers (Invited Paper) [8810-81]

B. del Rosal, P. Haro-González, Univ. Autonoma de Madrid (Spain); W. T. Ramsay, Scottish Univ. Physics Alliance (United Kingdom) and Heriot Watt Univ. (United Kingdom);

L. M. Maestro, Univ. Autonoma de Madrid (Spain); K. Santacruz-Gómez, Univ. de Sonora (Mexico); M. Iglesias-de la Cruz, F. Sanz-Rodríguez, J. Y. Chooi, P. Rodríguez-Sevilla, Univ. Autónoma de Madrid (Spain); D. Choudhury, A. K. Kar, Scottish Univ. Physics Alliance (United Kingdom) and Heriot Watt Univ. (United Kingdom); J. G. García Solé, Univ. Autonoma de Madrid (Spain); L. Patterson, Scottish Univ. Physics Alliance (United Kingdom) and Heriot Watt Univ. (United Kingdom); D. Jaque, Univ. Autonoma de Madrid (Spain)

$88102 \mathrm{~B}$ Optical tweezers for precise control of micro-bubble arrays: in situ temperature measurement [8810-82]

T. M. Burns, D. Preece, T. A. Niemenen, H. Rubinsztein-Dunlop, Univ. of Queensland (Australia) 
$88102 \mathrm{~F}$ Optical trapping for tissue scaffold fabrication [8810-86]

A. Linnenberger, C. Fiedler, J. J. Roberts, S. C. Skaalure, S. J. Bryant, M. C. Cole,

R. R. McLeod, Univ. of Colorado (United States)

POSTER SESSION

$88102 \mathrm{M}$ Surface-plasmon-based optical trapping of hard nanoparticles: two-dimensional closely packed assembly of polystyrene nanospheres on a metallic nanostructure [8810-94] T. Shoji, Hokkaido Univ. (Japan); H. Ishihara, Osaka Prefecture Univ. (Japan); Y. Tsuboi, Hokkaido Univ. (Japan) and Japan Science and Technology Cooperation (Japan)

$88102 \mathrm{~N}$ Optimization of the diffraction efficiency of a spatial light modulator through phase error minimization [8810-95]

M. A. Cibula, D. H. McIntyre, Oregon State Univ. (United States)

881020 Combined single-molecule manipulation and localization for the study of lac Repressor 1D-diffusion along DNA [8810-96]

G. Belcastro, C. Mónico, European Lab. for Non-linear Spectroscopy (Italy); M. Capitanio, F. Vanzi, European Lab. for Non-linear Spectroscopy (Italy) and Univ. degli Studi di Firenze (Italy); F. S. Pavone, European Lab. for Non-linear Spectroscopy (Italy) and Univ. degli Studi di Firenze (Italy) and National Institute of Optics-CNR and International Ctr. of Computational Neurophotonics (Italy)

$88102 Q \quad$ Ray optics in combination with the Gaussian beam propagation method for optical trapping of free-shaped particles in micro fluidic systems [8810-98]

D. De Coster, P. Wuytens, H. Ottevaere, H. Thienpont, Vrije Univ. Brussel (Belgium)

8810 2R Numerical simulation of Brownian particles in optical force fields [8810-99]

G. Volpe, Institut Langevin, ESPCI ParisTech, CNRS (France); G. Volpe, Bilkent Univ. (Turkey)

881025 Intracavity optical trapping with Ytterbium doped fiber ring laser [8810-100]

R. Sayed, Istituto Processi Chimico-Fisici, CNR (Italy) and Univ. degli studi Messina (Italy); F. Kalantarifard, P. Elahi, F. O. Ilday, G. Volpe, Bilkent Univ. (Turkey); O. M. Maragò, Istituto Processi Chimico-Fisici, CNR (Italy)

$88102 T \quad$ Rayleigh scattering correlation spectroscopy on diffusion dynamics of nanoparticles under intense laser irradiation [8810-101]

P.-Y. Hee, National Chiao Tung Univ. (Taiwan); T. Uwada, Josai Univ. (Japan); K. Okano,

A. Miura, H. Masuhara, National Chiao Tung Univ. (Taiwan)

$88102 \mathrm{~V}$ Optical trapping of anisotropic nanocylinder [8810-103]

P. B. Bareil, Y. Sheng, Univ. Laval (Canada)

$88102 Z$ Manipulation of yeast cells with DOE-modulated crescent-shaped and optical bottle laser beams [8810-107]

M. A. Rykov, R. V. Skidanov, Image Processing Systems Institute (Russian Federation) 
881030 Direct measurement of formation of loops in DNA by a human tumor suppressor protein [8810-108]

A. Migliori, S. Kung, Univ. of California, San Diego (United States); D. Wang, Univ. of California, San Diego (United States) and Univ. of California, Irvine (United States);

D. E. Smith, Univ. of California, San Diego (United States)

881032 Testing a structural model for viral DNA packaging motor function by optical tweezers measurements, site directed mutagenesis, and molecular dynamics calculations [8810-110]

N. A. Keller, A. D. Migliori, G. Arya, Univ. of California, San Diego (United States); V. B. Rao, Catholic Univ. of America (United States); D. E. Smith, Univ. of California, San Diego (United States)

881033 Evidence for non-equilibrium dynamics in viral DNA packaging from optical tweezers measurements [8810-111]

Z. T. Berndsen, N. Keller, D. E. Smith, Univ. of California, San Diego (United States)

881034 Analysis of single-molecule mechanical measurements with high spatio-temporal resolution [8810-1 12]

M. Capitanio, European Lab. for Non-linear Spectroscopy (Italy) and Univ. degli Studi di Firenze (Italy); L. Gardini, European Lab. for Non-linear Spectroscopy (Italy); F. S. Pavone, European Lab. for Non-linear Spectroscopy (Italy) and Univ. degli Studi di Firenze (Italy) and National Institute of Optics-CNR and International Ctr. of Computational Neurophotonics (Italy)

Author Index 
Proc. of SPIE Vol. $8810881001-10$

Downloaded From: https://www.spiedigitallibrary.org/conference-proceedings-of-spie on 26 Apr 2023 Terms of Use: https://www.spiedigitallibrary.org/terms-of-use 


\title{
Conference Committee
}

\author{
Symposium Chairs
}

Satoshi Kawata, Osaka University (Japan)

Manijeh Razeghi, Northwestern University (United States)

Symposium Cochairs

David L. Andrews, University of East Anglia Norwich (United Kingdom)

James G. Grote, Air Force Research Laboratory (United States)

Conference Chairs

Kishan Dholakia, University of St. Andrews (United Kingdom)

Gabriel C. Spalding, Illinois Wesleyan University (United States)

\section{Session Chairs}

1 Tractor Beams and the Positives and Negatives of Radiation Pressure

Miles J. Padgett, University of Glasgow (United Kingdom)

2 'Gonzo' Trapping

Gabriel C. Spalding, Illinois Wesleyan University (United States)

3 Toward (or in) the Quantum Limit of Opto-Mechanics

Israel De Leon, University of Ottawa (Canada)

4 Foundations of the Electromagnetic Theory of Force and Momentum

Michelle L. Povinelli, The University of Southern California (United States)

5 Optical Manipulation of Matter Through Gaseous Media

Yoshihiko Arita, University of St. Andrews (United Kingdom)

6 Photonic Devices for Optically Induced Forces

Masud Mansuripur, College of Optical Sciences, The University of Arizona (United States)

$7 \quad$ Plasmonic and Nanoparticle Trapping

Giovanni S. Volpe, Bilkent University (Turkey)

8 Statistical Mechanics of Small Systems

H. Daniel Ou-Yang, Lehigh University (United States)

9 Studies of Active Swimmers/Hydrodynamics

Halina Rubinsztein-Dunlop, The University of Queensland (Australia) 
10 Tutorial: Studying Single Molecules with Sub-nanometer Precision Jens-Christian D. Meiners, University of Michigan (United States)

11 Single-Molecule Manipulation and Study

Thomas T. Perkins, JILA (United States)

12 Using the Photonic Toolbox to Study Cells and Their Organelles Michael W. Berns, University of California, San Diego (United States)

13 Optically Driven Microrheology and Mechanical Properties Kishan Dholakia, University of St. Andrews (United Kingdom)

14 Optofluidics and Optically Shaped Structures

Etienne Brasselet, Université Bordeaux 1 (France)

15 The Challenges of Depth

Gabriel C. Spalding, Illinois Wesleyan University (United States)

16 Optically Bound Matter

Peter J. Reece, The University of New South Wales (Australia)

17 Optically Manipulated Robotics and Novel Samples

Simon Hanna, University of Bristol (United Kingdom) 